TA ІНЖЕНЕРІЯ

УдК: 61.001:615.1001:378.2:007:001.8:002.6:004:681.31:[334.722.008.8:351.862.4]

DOI: http://dx.doi.org/10.11603/mie.1996-1960.2016.2.6475

\title{
ІНФОРМАЦІЙНІ АСПЕКТИ ЗАБЕЗПЕЧЕННЯ ЕФЕКТИВНОСТІ ДЕРЖАВНО-ПРИВАТНОГО ПАРТНЕРСТВА В МЕДИЧНІЙ ТА ФАРМАЦЕВТИЧНІЙ НАУЦІ ТА ОСВІТІ. СТРАТЕГІЯ УПРАВЛІННЯ
}

\author{
О. П. Мінцер, Н. О. Сінєнко ${ }^{1}$, Г. В. Загорій \\ Національна медична академія післядипломної освіти імені П. Л. Шупика \\ 1 Національна академія державного управління при Президентові України
}

\begin{abstract}
Статтю присвячено дослідженню моделей та механізмів забезпечення ефективності державно-приватного партнерства в медичній та фрармацевтичній науці та освіті. Підкреслюється, що в медичній та фармацевтичній освіті в Україні наявні лише поодинокі випадки здійснення ефективного державно-приватного партнерства. Пропонуються нові підходи, пов'язані зі створенням «трикутника знань». Для зменшення можливих фінансових ризиків запропоновано створення резервного фонду, що буде тактичним та технологічним демпфером зміни ризиків зовнішньої системи.
\end{abstract}

Ключові слова: державно-приватне партнерство, стратегія управління, інформаційні технології, кластеризація простору послуг, органи державної влади, резервний фонд захисту інтересів.

\section{ИНФОРМАЦИОННЫЕ АСПЕКТЫ ОБЕСПЕЧЕНИЯ ЭФФЕКТИВНОСТИ ГОСУДАРСТВЕННО-ЧАСТНОГО ПАРТНЕРСТВА В МЕДИЦИНСКОЙ И ФАРМАЦЕВТИЧЕСКОЙ НАУКЕ И ОБРАЗОВАНИИ. СТРАТЕГИЯ УПРАВЛЕНИЯ}

\begin{abstract}
О. П. Минцер, Н. А. Синенко ${ }^{1}$, Г. В. Загорий Национальная медицинская академия последипломного образования имени П. Л. Шупика 1 Национальная академия государственного управления при Президенте Украины

\footnotetext{
Статья посвящена исследованию моделей и механизмов обеспечения эффективности государственно-частного партнерства в медицинской и фармацевтической науке и образовании. Подчеркивается, что в медицинском и фармацевтическом образовании в Украине имеются лишь единичные случаи осуществления эффективного государственно-частного партнерства. Предлагаются новые подходы, связанные с созданием треугольника знаний. Для уменьшения возможных финансовых рисков предложено создание резервного фонда, который будет тактическим и технологическим демпфером изменения рисков внешней системы.
}

Ключевые слова: государственно-частное партнерство, стратегия управления, информационные технологии, кластеризация пространства услуг, органы государственной власти, резервный фонд защиты интересов.

\section{INFORMATION ASPECTS OF ENSURING THE EFFECTIVENESS OF PUBLIC-PRIVATE PARTNERSHIPS IN THE MEDICAL AND PHARMACEUTICAL SCIENCE AND EDUCATION. MANAGEMENT STRATEGY}

\author{
O. P. Mintser, N. O. Sinyenko', G. V. Zagorii \\ Shupyk National Medical Academy of Postgraduate Education \\ ${ }^{1}$ National Academy for Public Administration under the President of Ukraine

\begin{abstract}
The article is devoted to research of models and mechanisms to ensure the effectiveness of public-private partnerships in medical and pharmaceutical science and education. It is emphasized that in medical and pharmaceutical education in Ukraine there are only isolated cases of implementation of effective public-private partnership. The new approaches related to the creation of knowledge triangle are proposed. To reduce potential financial risks the creation of reserve fund that will be a tactical and technological damper of change of risks of external system is prompted.
\end{abstract}

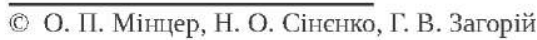


Key words: public-private partnership, strategy management, information technology, space clustering services, public authorities, reserve advocacy.

Вступ. Стало загальновизнаним, що державноприватне партнерство (ДПП) $є$ ефективним та перспективним інструментом економічного та соціального розвитку країни, важливим елементом управління державою на всіх їі рівнях, необхідним засобом залучення коштів для виконання проектів $[1,2,3]$. Головною метою Концепції розвитку ДПП в Україні на 2013-2018 роки, схваленої Урядом 14 серпня 2013 року, стало формування національної моделі розвитку ДПП з урахуванням інституціональних особливостей і сучасних умов залучення інвестицій та розвитку національної економіки на інноваційній основі [4].

ДПП - це нова технологія розвитку економіки [5], що дає змогу ефективно об'єднати ресурси приватного та державного секторів, інституційний та організаційний альянс між державою і бізнесом 3 метою реалізації як національних, так і міжнародних проектів (як правило, суспільно значущих у широкому спектрі сфер діяльності). При цьому діапазон завдань, що вирішуються, досить широкий - від розвитку стратегічно важливих галузей промисловості та науково-дослідних конструкторських робіт до забезпечення суспільних послуг [6].

Проте забезпечення механізмів ефективного ДПП досліджено поки що недостатньо. Відсутня відповідна інформаційна політика стосовно просування соціально-економічних переваг державноприватної взаємодії; відсутні відповідні пруденційні узгодження між учасниками взаємодії при ДПП, немає розуміння нового розподілу ролей та прийняття його інституціональних засад.

Мета роботи: обгрунтування теоретичних та методологічних засад ДПП в сфері медичної та фармацевтичної науки та освіти, розроблення пропозицій щодо вдосконалення інструментарію реалізації ДПП в Україні.

Матеріали та методи. Проаналізовано систематичні огляди, публікації останніх років із використанням методів метааналізу, порівняльного та статистичного аналізу, системних узагальнень та групування, системно-структурного аналізу, структурної декомпозиції.

\section{Результати та їх обговорення.}

Постановка проблеми. Виходячи 3 того, що предметом ДПП є суспільні відносини двох і більше суб'єктів, інформаційні стосунки включають у себе низку процесів: комунікацію, отримання й оцінку інформації, елементи прийняття рішень, інтерактивні процеси і соціальну перцепцію. Підкреслимо, що саме взаємний обмін і оцінка отриманої інформації є сполучною ланкою між початком відносин між партнерами і подальшою реалізацією поставлених даними партнерами завдань.

Використовуються різні моделі ДПП: концесійні угоди, державні корпорації, фонди, створені з метою реалізації інвестиційних проектів, державні цільові програми, договори довірчого управління майном, спільно фінансовані підприємства. Більше питань викликають договори на виконання науково-дослідних робіт та дослідно-конструкторських робіт. Поряд із зазначеними формами в зарубіжній літературі виділяються проекти делегованого управління, фінансової ініціативи приватних інвесторів, greenfield-проекти, концесійні форми ВОТ (побудуй, управляй, передай) і ROT (віднови, володій, передай) [7, 8]. Новою для України є тенденція використання контрактів життєвого циклу. Для них характерне те, що за рахунок приватного капіталу забезпечується створення проектно-кошторисної документації, будівництво, ремонт, обслуговування та експлуатація об'єкта протягом усього життєвого циклу. Держава гарантує оплату функціонування рівними частинами протягом усього терміну служби об'єкта, а починає оплачувати сервіс лише 3 моменту його доступності, тобто, з моменту здачі об'єкта в експлуатацію. Вважається, що формат контрактів життєвого циклу однаково вигідний як державі, що ефективніше витрачає бюджетні кошти, так і інвестору, який отримує довгостроковий контракт, що суттєво менше залежить від ризику попиту та інших ринкових факторів [9].

Міжнародна практика показала, що у кожної форми ДПП є свої переваги та недоліки, а вибір конкретної форми залежить від цілей, переслідуваних у моделі [10]. Головним фактором, що обумовлює успішність ДПП останнім часом, стає використання інформаційних технологій, які дають певну гарантію оптимізації, раціоналізації та передбачуваності процесу діяльності, отримання заданих властивостей і якостей результату діяльності. Розвинуті та єдині інформаційний простір, а також інформаційне середовище для формування та розвитку інститутів громадянського суспільства, які входять до складу ДПП, є абсолютно необхідними умовами його існування. Виділимо такі основні ознаки інформаційного суспільства, що $\epsilon$ ключовим фактором використання ДПП: поши- 
рення інформації набуває глобального характеру, державні кордони перестають впливати на рух інформаційних потоків; спроби обмежити вільне поширення інформації обертаються серйозними технологічними проблемами, насамперед для тієї країни, що намагається ввести ці обмеження; істотно зростають технічні можливості збору, оброблення, зберігання, передавання та доступу до інформації, у тому числі політичної; посилюється вплив інформаційних технологій на всі сфери людської діяльності, поглиблюється процес децентралізації суспільства; відбувається перехід до нових форм зайнятості та формування нових трудових ресурсів за рахунок збільшення кількості осіб, зайнятих в інформаційній сфері.

Підкреслимо також, що перехід до нової, мережевої моделі публічного управління дає поштовх, у свою чергу, до розвитку інформаційно-комунікаційних технологій в організації сучасного процесу управління [11], що виражається в реалізації концепції переходу технологій електронного уряду до технології електронного управління. Беручи до уваги суттєву принциповість та значення цього положення, зупинимося на ньому детальніше.

Електронний уряд у сучасному уявленні складається 3 досить великої кількості модулів (G2G, уряд - урядові; G2B, уряд - бізнесу; G2C, уряд громадянам; G2IR, уряд - міжнародним відносинам; G2I, уряд - інноваціям тощо). Електронний уряд має забезпечувати свободу доступу громадян до державної інформації, переведення державних органів на безпаперове діловодство, автоматизований контроль діяльності органів влади тощо. Втім, повноцінна реалізація комплексної програми електронного уряду відбувається далеко не в повному обсязі. Центральним у даному випадку стає розуміння чиновниками сенсу запровадження інформаційно-технологічних перетворень, адекватна оцінка власної ролі в інноваційних процесах $[12,13]$. Можна констатувати, що це питання в Україні вирішується недостатньо. Відповідно, перехід до електронного управління надалі стає все актуальнішим та очікуванішим.

Особливості застосування ДПП в медичній та фармацевтичній науці та освіті. Актуальним останнім часом стає пошук принципово нових моделей інтеграції держави, науки, освіти і бізнесу. Саме для цих напрямків найбільш значущим стає диверсифікація джерел фінансування науково-дослідних робіт, виробничих технологій (гранти, договори з господарськими суб'єктами, реалізація наукових розробок, наукове консультування, експер- тиза, інформаційні послуги, проектні, організаційні послуги, реалізація патентів, ліцензій тощо). Очевидно, що диверсифікація фінансування процесів інтеграції науки та бізнесу сприяє стійкому попиту на виробничо-технологічні інновації. Одним 3 напрямків підтримки підприємництва та інтенсивності інноваційного процесу є розвиток територіальних науково-виробничих систем - наукових парків, інноваційних технологічних центрів, інкубаторів нововведень тощо.

Однак в умовах України на сьогоднішній день попит на технологічні інновації є низьким - кількість вітчизняних промислових підприємств, що купують інтелектуальні розробки з метою запровадження, становить менше $3 \%$ [14].

Інноваційні проекти ДПП наукомістких виробництв у своєму формуванні засновані на знаннях, де важливою є сфера професійної освіти, в якій генеруються компетенції - ключові ресурси суспільства. Ефективність функціонування сфери освіти фактично формує успіх соціально-економічного розвитку країни в цілому.

Інтеграція освіти та бізнесу сприяє підвищенню інноваційного потенціалу національної економіки. Оскільки успішність у бізнесі залежить від здатності персоналу промислових компаній швидко перебудовувати свою діяльність у мінливих умовах, то вітчизняний бізнес, як зацікавлена особа, сьогодні готовий фінансово підтримати реформу в освіті на умовах партнерства, взяти участь у формуванні національної системи кваліфікацій, професійних освітніх стандартів, незалежної оцінки якості освіти та сертифікації кваліфікації в ході навчання, у здійсненні моніторингу потреби економіки в кадрах фахівців, взяти участь в управлінні навчальними закладами. Механізм ДПП має вагомий позитивний ефект в процесі реалізації проектів, пов'язаних з інвестуванням у оновлення матеріально-технічної бази начальних закладів у обмін на отримання приватними інвесторами частини прибутку від сумісної діяльності, популяризації та реалізації запланованих проектів. Запровадження ДПП передбачає розширення конкурентного сектору, надання кращих можливостей для мобілізації коштів на масштабні інвестиційні проекти, ефективний розвиток чи модернізацію інфраструктури [15].

Тому вкрай важливим є зміцнення механізму комерціалізації результатів наукових досліджень та розробок, надання фінансової підтримки з боку держави на випуск інноваційної продукції, надання органами влади допомоги підприємствам 
та науково-дослідним установам у запровадженні у виробництво науково-технічних розробок, сприяння розбудові мережі інноваційної інфраструктури - технополісів і технопарків.

До тепер в Україні не зафіксовано випадків успішного залучення приватних інвестицій на засадах ДПП до реалізації стратегічно важливих соціально-гуманітарних проектів (у тому числі у сфері освіти та охорони здоров'я). Вважаємо, що на це є кілька причин. Перш за все, слід відзначити недосконалість вітчизняної нормативно-правової бази [7, 15] (зокрема, існують досить суттєві труднощі з отриманням приватним інвестором дозвільних документів та погоджень, необхідних для виконання умов договору), у якій не передбачено норм, що існують у розвинених країнах світу (обговорення умов виплати приватним власникам компенсацій у випадку невиконання державою своїх зобов'язань за укладеними договорами, відшкодування різниці у тарифах тощо). Слід враховувати, що сучасна система бюджету освіти та науки, особливо в галузі охорони здоров'я України, створює певні фінансові ризики для функціонування ДПП, що пов'язане, насамперед, із наявністю коротких (річних) бюджетних циклів і щорічною процедурою затвердження державного та місцевих бюджетів. Аналізуючи процеси стимулювання та чинники стримування ДПП, можна також звернути увагу на недостатність законодавчих та нормативно-правових документів (які регулюють і стимулюють інноваційну діяльність) $[15,16]$, нерозвиненість інноваційної інфраструктури, невизначеність економічної вигоди від використання інтелектуальної власності, нестачу інформації про нові технології, ринки збуту.

На жаль, слабо використовується досвід країн ЄС щодо співпраці держави та бізнесу на засадах ДПП у гуманітарній сфері. Українське законодавство розглядає ДПП, обмежуючись лише формою договору між державою та приватним сектором (договір концесії, оренди державного майна, лізингу, угода про розподіл продукції чи управління державним майном) [7], а країни Свропи давно вже використовують кластери як організаційні об'єднання державного та приватного партнерства за участю фінансових установ із правом випуску фінансових інструментів (наприклад, облігацій).

Головне, що не використовується пріоритет сучасного суспільства-розвиток та інтеграція елементів «трикутника знань»: освіти, дослідження, інновацій. Саме при такому підході ефективною є стратегія інноваційного розвитку, що припускає набуття та збереження технологічних переваг (конкурентоздатності). Підкреслимо, що створення «трикутника знань» надає гарантованої можливості експоненціального зростання ДПП на певному проміжку часу.

Практично не використовується принцип компліментарності під час визначення взаємної вигоди та спільної відповідальності, що було б доцільним для узгодження навіть протилежних, на перший погляд, інтересів (йдучи на певні самообмеження, партнери досягають більшого результату, зокрема завдяки загальному соціальному ефекту, ніж кожен iз них може досягти самостійно).

Недостатньо використовуються й сучасні аналітичні підходи: SWOT- та PEST-аналіз, експертиза динаміки потреби у суспільних товарах і послугах, експертиза перспектив участі бізнес-структури в реалізації проектів ДПП, карта стейкхолдерів (що дозволяє провести аналіз можливостей опортуністичної поведінки партнерів), експертні оцінки ризиків тощо.

В Україні, згідно з даними статистики, налічується близько 3,5 тис. організацій, які займаються науковими дослідженнями і розробками; в державній власності сконцентровано понад 70 \% науковотехнічного потенціалу країни [14]. Державний сектор науки включає академії наук, наукові центри та наукові організації вищої школи. За формою власності науково-дослідні організації представлені державними унітарними підприємствами, державними установами та акціонерними товариствами 3 державною участю в капіталі. Основні кошти для фінансування наукової, інноваційної та господарської діяльності науково-технологічної сфери України надходять 3 державного бюджету. М. Ю. Авксентьєв [6] відзначає організаційно-фінансову залежність від держави і повну несприйнятливість до приватних інвестицій як головний недолік українського державного сектора досліджень і розробок, що негативно позначається на інноваційному процесі, призводить до деградації науково-технічної бази та втрати науковими установами самостійності у створенні нововведень, втрати переваг у виробництві принципово нової продукції. Дослідник виділяє наступні основні проблеми українського наукового сектору: множинність суб'єктів науки у поєднанні 3 обмеженістю бюджетних ресурсів, відсутність реальних пріоритетів у політиці бюджетного фінансування, дефіцит молодих спеціалістів у науково-технічній сфері, переважно кошторисне фінансування фундаментальних досліджень, низька капіталізація інтелектуальної 
власності та недостатня патентна активність наукових організацій. Можна погодитись 3 думкою авторів, що до організаційних недоліків вітчизняної науки слід віднести розриви в інноваційному ланцюжку, відсутність тісного взаємозв'язку між освітньою та науковою діяльністю, розпорошеність по різних державних відомствах ресурсів державного бюджету на проведення наукових досліджень та запровадження нових технологій.

Отже, партнерство одержавленої української науки з бізнесом все ще перебуває в нерозвиненому стані, який ніяк не узгоджується із завданнями модернізації економіки.

Аналогічних висновків можна дійти, аналізуючи ефективність запровадження ДПП в освіті, де подібний альянс слід узагальнити як систему довгострокових відносин між державою та суб'єктами приватного сектора економіки з реалізації інвестиційних проектів у сфері професійної освіти на основі об'єднання ресурсів і розподілу доходів чи немайнових вигод, витрат і ризиків.

Саме ДПП могло б надати державі вже на перших кроках свого існування можливості отримання розвиненого конкурентного ринку освітніх послуг, апробації застосування нових для освітніх структур організаційно-правових форм альянсу з бізнесом, вироблення пропозицій щодо подальшого вдосконалення нормативно-правової бази реформування професійної школи, вдосконалення системи управління у сфері інноваційної діяльності.

Особливо актуальною проблемою є виробництво освітніх та науково-технічних досягнень на стику освіти, науки та бізнесу. Перспективні інноваційні форми ДПП в сфері освіти, науки та бізнесу представляють різні види інтеграційних комплексів для здійснення спільної діяльності, що становить інтерес для приватного сектора промисловості. Інтереси держави щодо створення навчально-науково-виробничих комплексів викликані необхідністю забезпечення підготовки та перепідготовки кваліфікованих наукових та науково-педагогічних кадрів вищої кваліфікації, залучення молодих вчених та студентів до науково-технічної та інноваційної діяльності; інтереси бізнесу - можливістю отримання нових знань для організації інноваційного виробництва 3 метою виведення на ринок конкурентоспроможної наукомісткої продукції та послуг. Відповідно особливої значущості набуває трансдисциплінарне навчання в рамках післядипломної освіти.

Резюмуючи сказане, підкреслимо, що вітчизняні освіта, наука та бізнес перебувають на стадії по- шуку життєздатних форм тристоронньої інтеграції, заснованих на мережевому принципі взаємодії в рамках спільних центрів, лабораторій, навчальнонауково-виробничих комплексів, які дозволяють зрівнювати учасників, різних за інституційною та організаційною специфікою [14].

Невеликий досвід реалізації інвестиційних проектів із використанням механізмів ДПП в Україні свідчить про необхідність подолання різного роду множинних адміністративно-відомчих бар'єрів, які найбільшою мірою гальмують запуск ДППмеханізмів в регіонах. Незважаючи на наявність варіативних освітніх програм і можливості вибору професії та самореалізації особистості, українська система освіти недостатньо націлена на формування базових практично орієнтованих навичок. Більше того, треба навчитися отримувати синергетичний ефект від використання можливостей промислового обладнання в навчальному процесі та цільових НДР, широкого обміну знаннями між вченими, викладачами та виробничниками [17].

Ключовим завданням в освітній сфері є розвиток системи безперервної освіти, створення ефективної системи стимулів та інфраструктурних умов для постійної перепідготовки та підвищення кваліфікації всього економічно активного населення країни.

Ризики функціонування ДПП та методи управління. Зважаючи на особливий характер роботи ДПП та реальні фінансові ризики, державою ретельно розглянуто та затверджено постановою Кабінету Міністрів України від 16 лютого 2011 р. № 232 методику виявлення ризиків здійснення ДПП (далі - Методика), їх оцінювання та визначення форми управління ними [18]. Вона застосовується під час проведення аналізу ефективності здійснення ДПП, прийняття рішень про його здійснення, розподіл ризиків між державним і приватним партнерами на кожному етапі здійснення ДПП, укладення договору між вказаними сторонами.

Зрозуміло, що при використанні Методики перше питання, яке виникає, пов'язано з логікою використання алгоритмів аналізу. В п. 10 Методики підкреслюється, що ризик оцінюється на основі історичних даних, прийнятих технічних моделей або експертних висновків. Зрозуміло, що вибір належного методу проведення оцінки (або поєднання методів) залежить від конкретного виду ризику. Але з точки зору практичності слід зауважити, що далеко не завжди в умовах багатофакторності реального існування ДПП можна достатньо точно 
визначити ступінь того чи іншого фактору ризику. Більше того, далеко не завжди можливо об'єктивно ідентифікувати небезпеку, появу конфліктів та їх оптимальне вирішення.

3 метою зменшення фінансових ризиків можна передбачити можливість залучення механізму проектного планування і фінансування проектів ДПП, що сприятиме підвищенню зацікавленості приватних вітчизняних та іноземних інвесторів до участі в ДПП. Додатковими стимулами для залучення приватних партнерів можуть бути такі преференції: надання державою пільг на податки та зміна термінів їх сплати, субсидування інвесторів iз державного бюджету на оплату частини відсотків за банківськими кредитами, пропозиції з боку держави щодо залучення приватного інвестора до програм державного кредитування, спрощені процедури отримання кредиту для соціального інвестування, формування пілотних інвестиційних майданчиків і медичних технопарків [7, 12, 19].
Відповідно нами запропоновано створення на паритетних началах резервного фінансового фонду, що може використовуватися в екстремальних ситуаціях як для корекції ситуації, так і для оперативного зниження ризику призупинення діяльності ДПП. Це має виключне значення особливо при створенні ДПП в напрямку наукового пошуку.

Висновки. 1. Приклади успішного залучення приватних інвестицій на засадах ДПП до реалізації стратегічно важливих соціально-гуманітарних проектів (у першу чергу у сфері освіти та охорони здоров'я) в Україні поодинокі. Це обумовлено недостатнім запровадженням сучасної стратегії використання «трикутника знань».

2. Ключове значення в забезпеченні ефективності ДПП має використання інформаційно-технологічних перетворень, зокрема електронного уряду.

3. Важливим елементом зниження ризиків при створенні інструментів ДПП може слугувати організація вже на перших кроках резервного фонду.

\section{Література.}

1. Деякі питання організації здійснення державно-приватного партнерства : постанова Кабінету Міністрів України від 11 квітня 2011 р. № 384 // Офіційний вісник України. - 2011. - № 28. - Ст. 1168.

2. Деякі питання проведення аналізу ефективності здійснення державно-приватного партнерства : наказ Міністерства економічного розвитку і торгівлі України від 27.02.2012 № 255 (зареєстровано в Міністерстві юстиції України 15 березня 2012 р. № 399/20712) [Електронний ресурс] / база даних «Законодавство України»; офіційний веб-портал Верховної Ради України. - Режим доступу : http://zakon3.rada.gov.ua/laws/show/z0399-12.

3. Про державно-приватне партнерство : Закон України від 01.07.2010 № 2404-VI [Електронний ресурс] / база даних «Законодавство України»; офіційний веб-портал Верховної Ради України. - Режим доступу: http://zakon2. rada.gov.ua/laws/show/2404-17.

4. Про схвалення Концепції розвитку державно-приватного партнерства в Україні на 2013-2018 роки : розпорядження Кабінету Міністрів України від 14 серпня 2013 р. № 739-р [Електронний ресурс] / база даних «Законодавство України» ; офіційний веб-портал Верховної Ради України. - Режим доступу : http://zakon4.rada.gov.ua/laws/ show/739-2013-p.

5. Айрапетян М. С. Зарубежный опыт использования государственно-частного партнерства [Электронный ресурс] / М. С. Айрапетян // Информационно-аналитические материалы Государственной Думы. - (Серия экономическая политика. Аналитическая записка). - А3, 2008, декабрь. - Режим доступу : http://pda.iam.duma.gov.ru/node/3/4669. 6. Авксентьєв М. Ю. Державно-приватне партнерство як сучасний механізм залучення інвестицій в інфраструктури галузі України : автореф. дис. ... канд. екон. наук : спец. 08.00.03 «Економіка та управління національним господарством» / М. Ю. Авксентьєв. - К., 2010. - 20 с.

7. Запатріна I. В. Державно-приватне партнерство як фактор економічного зростання та проблеми його розвитку в Україні / I. В. Запатріна, Т. Б. Лебеда // Економіст. - 2011. - № 3. - С. 52-58.

8. Delmon J. J. Understanding options for public-private partnerships in infrastructure. Sorting out the forest from the trees: BOT, DBFO, DCMF, concession, lease./ J. J. Delmon // The World Bank ; Finance Economics \& Urban Department ; Finance and Guarantees Unit. - January 2010. - Policy Research Working Paper 5173. - 75 p.

9. Павлюк К. В. Сутність і роль державно-приватного партнерства в соціально-економічному розвитку держави / К. В. Павлюк, С. М. Павлюк // Наукові праці КНТУ Економічні науки. - 2010. - № 17. - С. 10-19.

10. Узунов Ф. В. Зарубіжний досвід формування та розвитку державно-приватного партнерства / Ф. В. Узунов // Інвестиції: практика та досвід. - 2013. - № 14. - С. 124-126.

11. Купріяненко Л. В. Розробка стратегій комунікативних компаній у різних сферах державного управління / Л. В. Купріяненко // Економіка та держава. - 2009. - Т. 80, № 8. - С. 91-94.

12. Дынин Е. А. Риски бизнеса в частно-государственном партнерстве / Е. А. Дынин // Общество и экономика. 2007. - № 5-6. - C. 111. 
13. Узунов Ф. В. Інвестиційне партнерство держави та приватного сектору в галузях інфраструктури України / Ф. В. Узунов // Інвестиції: практика та досвід. - 2013. - № 19. - С. 104-107.

14. Нейкова I. С. Державно-приватне партнерство як складова інвестиційного механізму інноваційного розвитку / I. С. Нейкова // Науковий вісник Національного університету ДПС України (економіка, право). - 2010. - Т. 48, №1. - C. 152-160.

15. Мартякова О. В. Державно-приватне партнерство у сфері охорони здоров'я / О. В. Мартякова, І. В. Трикоз // Вісник Бердянського університету менеджменту і бізнесу. - 2011. - Т. 13, № 1. - С. 37-43.

16. Запатрина И. Публично-частное партнерство как новая идеология развития мирового сообщества [Электронный ресурс] / И. Запатрина // сайт Українського центру сприяння розвитку публічно-приватного партнерства. - Режим доступа : www.ukrppp.com/present/doklad_astana_zapatrina.doc.

17. Узунов Ф. В. Формування концепції розвитку партнерських взаємовідносин держави, науки, освіти та бізнесу / Ф. В. Узунов // Наукові розвідки з державного та муніципального управління : зб. наук. пр. - К. : АМУ, 2014. Вип. 1/2014. - С. 114-123.

18. Про затвердження Методики виявлення ризиків здійснення державно-приватного партнерства, їх оцінки та визначення форми управління ними : постанова Кабінету Міністрів України від 16 лютого 2011 р. № 232 [Електронний ресурс] / база даних «Законодавство України»; офіційний веб-портал Верховної Ради України. - Режим доступу: http://zakon3.rada.gov.ua/laws/show/232-2011-п.

19. Узунов Ф. В. Індикатори оцінки безпеки партнерства бізнесу з органами влади / Ф. В. Узунов // Інвестиції: практика та досвід. - 2014. - № 1. - С. 153-155. 